\title{
Tindak Pidana Penganiayaan yang Menyebabkan Kematian Perspektif Hukum Positif dan Hukum Pidana Islam
}

\author{
Moh Alviyan ${ }^{1}$ \\ ${ }^{1}$ Fakultas Syariah, IAIN Jember. E-mail: malvian45@gmail.com
}

\begin{tabular}{|c|c|}
\hline Article & bstract \\
\hline $\begin{array}{l}\text { How to cite: } \\
\text { Moh. Alviyan, 'Tindak } \\
\text { Pidana Penganiayaan } \\
\text { yang Menyebabkan } \\
\text { Kematian Perspektif } \\
\text { Hukum Positif dan } \\
\text { Hukum Pidana Islam' } \\
\text { Vol. } 1 \text { No. } 1 \\
\text { Rechtenstudent Journal } \\
\text { Fakultas Syariah IAIN } \\
\text { Jember. } \\
\text { Histori artikel: } \\
\text { Submit } 14 \text { Februari 2020; } \\
\text { Diterima } 2 \text { Maret 2020; } \\
\text { Diterbitkan } 3 \text { April 2020. }\end{array}$ & 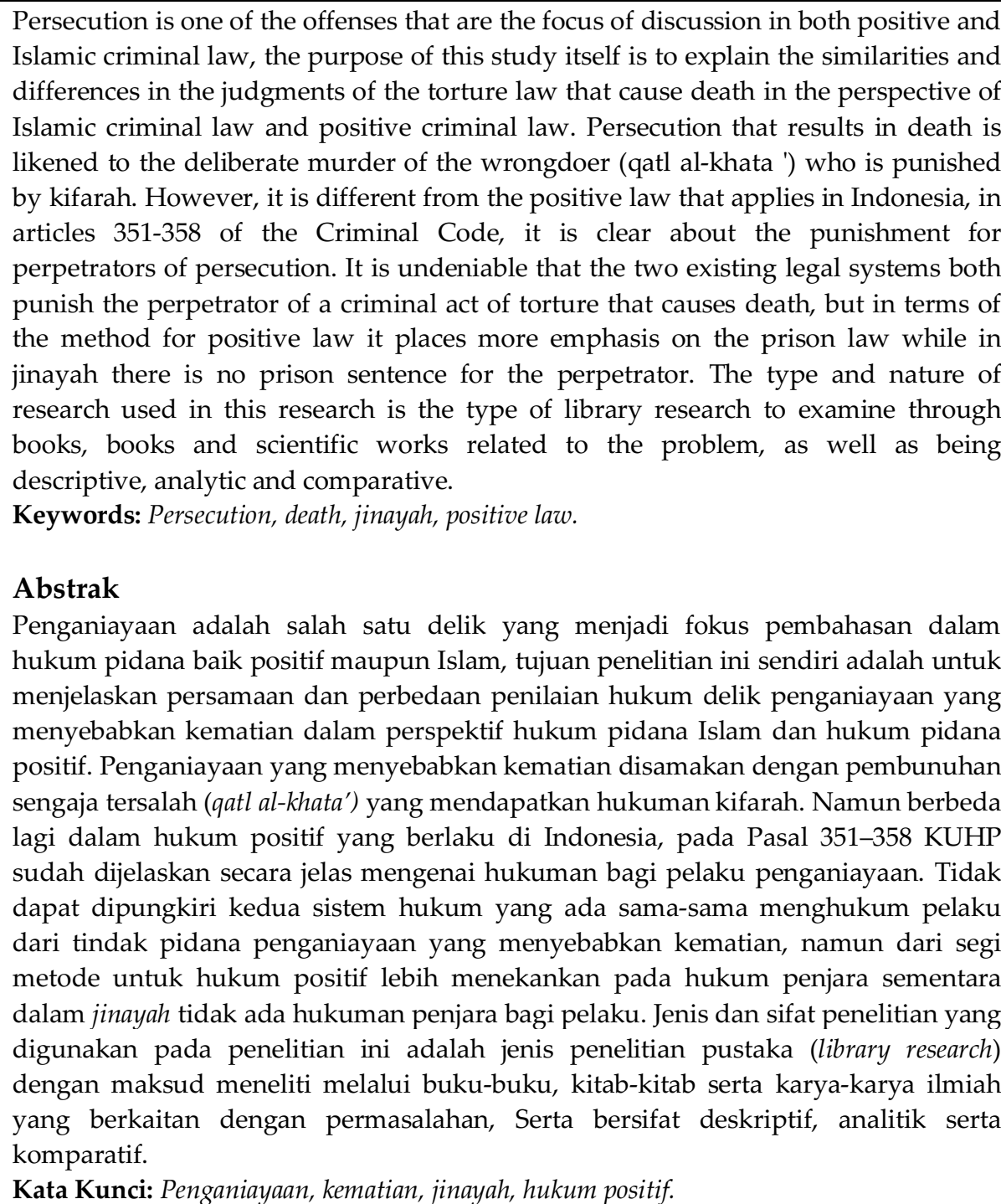 \\
\hline
\end{tabular}

\section{Pendahuluan}

Di negara Indonesia, hukum terbagi atas beberapa bagian. Menurut isinya, hukum terdiri dari hukum privat dan hukum publik. Inisiatif pelaksanaan hukum privat diserahkan kepada masing-masing pihak yang berkepentingan. Kedudukan antara individu adalah horizontal. Sedangkan inisiatif pelaksanaan hukum publik diserahkan kepada negara atau pemerintah yang diwakilkan kepada jaksa beserta perangkatnya. ${ }^{1}$

\footnotetext{
${ }^{1}$ Guru Geografi, <www.gurugeografi.id $>$ diakses pada tanggal 1 September 2018.
} 
Ditinjau dari fungsinya, hukum dibagi atas hukum perdata, hukum dagang dan hukum pidana. Masing-masing memiliki sifat dan fungsi yang berbeda-beda. Sebagai contoh, hukum pidana berfungsi untuk menjaga agar ketentuan-ketentuan hukum yang terdapat dalam hukum perdata, dagang, adat dan tata negara ditaati sepenuhnya. ${ }^{2}$

Delik penganiayaan merupakan salah satu bidang garapan dari hukum pidana. Penganiayaan oleh KUHP secara umum diartikan sebagai tindak pidana terhadap tubuh. Semua tindak pidana yang diatur dalam KUHP ditentukan pula ancaman pidananya. Demikian juga pada delik penganiayaan serta delik pembunuhan. Kedua delik ini ancaman pidananya mengacu pada Buku I Bab II tentang Pidana KUHP, terutama pada Pasal 10. Di dalam pasal tersebut disebutkan bahwa pidana terdiri dari dua macam, yaitu pidana pokok dan pidana tambahan. Melihat konteks dalam pasal tersebut maka delik penganiayaan serta pembunuhan lebih mengarah kepada pidana pokok yang terdiri atas pidana mati, pidana penjara, kurungan dan denda. ${ }^{3}$

Sementara itu, dalam Hukum Islam juga terdapat bermacam-macam hukum yang mengatur kehidupan manusia sebagai khalifah dibumi ini. Aturan hukum dalam Islam antara lain dibedakan sebagai al-Ahwal asy-Syakhsiyyah atau hukum keluarga, al-Ahwal al-Madaniyyah atau hukum privat, al-Ahwal al-Jinayah atau hukum pidana dan sebagainya.

Hukum Pidana Islam (jinayah) didasarkan pada perlindungan HAM (Human Right) yang bersifat primer (Daruriyyah) yang meliputi perlindungan atas agama, jiwa, keturunan, akal dan harta. Perlindungan terhadap lima hak tersebut oleh asy-Syatibi dinamakan maqasid asysyari'ah. Hakikat dari pemberlakuan syari'at (hukum) oleh Tuhan adalah untuk mewujudkan kemaslahatan manusia. Kemaslahatan itu dapat diwujudkan apabila lima unsur pokok tersebut dapat diwujudkan dan dipelihara. ${ }^{4}$

Mengenai masalah pembunuhan ataupun penganiayaan dalam pidana Islam diancam dengan hukuman qishas. Akan tetapi tidak semua pembunuhan dikenakan hukum qishas, ada juga yang sebatas dikenakan diat (denda). Salah satu contoh kasusnya yaitu pembunuhan atas dasar ketidaksengajaan yang dalam hal ini tidak dikenakan qishas melainkan hanya wajib membayar denda yang ringan. Denda ini diwajibkan atas keluarga yang membunuh, bukan atas yang membunuh. Mereka membayarnya dengan diangsur dalam masa tiga tahun, tiaptiap akhir tahun keluarga itu wajib membayar sepertiganya. ${ }^{5}$

Ketentuan-ketentuan hukum yang ada, baik pada hukum pidana Islam maupun pidana yang telah disebutkan di atas menjadi menarik untuk dibahas ketika keduanya dihadapkan pada suatu kasus yang menuntut adanya penyelesaian, dalam hal ini adalah kasus penganiayaan yang menyebabkan kematian.

Ada beberapa hal yang menjadikan penyusun tertarik untuk membahas kasus tersebut, yang pertama adalah bahwa belum adanya penelitian yang membahas kasus tersebut dari segi hukum pidana Islam dan hukum pidana, pada umumnya yang dibahas masih bersifat umum pada delik penganiayaan atau pembunuhan saja. Yang kedua adalah selama ini sering terjadi tindak-tindak kekerasan yang menimbulkan berbagai akibat, salah satunya adalah kasus penganiayaan seperti yang dikemukakan dalam penelitian ini. Sedangkan berkenaan dengan kasus-kasus tersebut belum ada ketegasan mengenai sanksi-sanksi hukumnya.

\footnotetext{
2 Ibid.

${ }^{3}$ Buchari said, Hukum Pidana Materil (Bandung: FH UNPAS, 2009), 67.

${ }^{4}$ Rokhmadi, Hukum Pidana Islam, (Semarang: Karya Abadi Jaya, 2015), 118.

${ }^{5}$ Ibid.
} 


\section{Rumusan Masalah}

Adapun rumusan masalah dalam penelitian ini adalah:

1. Bagaimanakah perspektif Hukum Islam tentang delik penganiayaan yang menyebabkan kematian?

2. Bagaimanakah perspektif Hukum Pidana tentang delik penganiayaan yang menyebabkan kematian?

3. Bagaimana perbedaan dan persamaan penilaian hukum delik penganiayaan yang menyebabkan kematian dalam perspektif Hukum Pidana Islam dan Hukum Pidana?

\section{Metode Penelitian}

Jenis penelitian yang digunakan penulis di dalam kepenulisan ini adalah penelitian pustaka (library research), yakni penelitian yang menggunakan fasilitas pustaka seperti buku, kitab atau majalah. ${ }^{6}$ Oleh karena itu, dalam penelitian ini dikaji berbagai sumber pustaka yang berkenaan dengan pokok permasalahan di atas, yang lebih jelasnya adalah membandingkan dan memahami ketetapan dari dua sistem hukum yang berbeda mengenai delik penganiayaan yang menyebabkan kematian melalui kajian pustaka.

Sifat penelitian ini adalah deskriptif, analitik serta komparatif. Metode deskriptif adalah menjelaskan suatu gejala atau fakta untuk memberikan data yang seteliti mungkin tentang gejala atau fakta tersebut.7 Sedangkan metode analitik adalah sebuah usaha untuk mencari dan menata secara sistematis data penelitian untuk kemudian dilakukan penelaahan guna mencari makna. ${ }^{8}$ Metode komparatif sendiri adalah dengan membandingkan hasil yang didapat, dalam hal ini perbandingan antara sistem hukum pidana Islam dan hukum pidana positif, sehingga dapat diperoleh suatu gambaran masalah dan landasan penyelesaian.

Adapun Pendekatan yang digunakan dalam penelitian ini adalah pendekatan yuridis normatif, yaitu dengan mengambil beberapa aturan atau ketentuan yang ada mengenai delik penganiayaan maupun pembunuhan yang bersumber dari hukum pidana Islam dan hukum pidana. Kemudian menjelaskan teks-teks yang memerlukan penjelasan, terutama dalam hukum pidana Islam.

Jenis penelitian dalam penelitian ini adalah penelitian kepustakaan, maka teknik pengumpulan data yang ditempuh adalah dengan meneliti melalui buku-buku, kitab-kitab serta karya-karya ilmiah yang berkaitan dengan permasalahan. Kemudian dari sumbersumber yang ada, baik primer maupun sekunder akan diuji kredibilitasnya untuk mendapatkan data yang benar-benar akurat. Adapun buku-buku ataupun kitab-kitab yang dijadikan sumber data dalam penelitian ini adalah, dari segi Hukum Islam: Kifayatul Akhyar karya Abu Bakar bin Muhammad Al-Husain, Fiqih Empat Madzhab terjemah dari Rahmah alUmmah fi Ikhtilaf al-A'immah karya Syaikh al-'Allamah Muhammad bin 'Abdurrahman adDimasyqi, dan Fathul Qarib Al Mujib karya Assyaikh Al-Imam Abi Abdillah Muhammad bin Qasim Alghozi. Dari segi hukum positif terdapat kitab undang-undang atau KUHP yang merupakan rujukan pokok dalam penentuan hukum di Indonesia. Dalam KUHP tersebut, dijabarkan mengenai delik penganiayaan, yaitu pada Buku II Bab XX Pasal 351-358.

\footnotetext{
${ }^{6}$ Winarno Surakhmad, Pengantar Penelitian Ilmiah: Dasar, Metode, Tehnik (Cet. Ke-7, Bandung: t.n.p., 1994$), 25$.

7 Soerjono Soekanto, Pengantar Penelitian Hukum (Cet. Ke-3, Jakarta: UI-Press, 1986), 10.

${ }^{8}$ Noeng Muhajir, Metodologi Penelitian Kualitatif (Cet. Ke-4, Yogyakarta: Roke Sarasin, 1998), 43.
} 
Metode analisis data yang digunakan dalam penelitian ini adalah analisa kualitatif dengan cara berfikir induktif, deduktif dan komparatif. Induktif adalah pengambilan kesimpulan dari pernyataan bersifat khusus ke pernyataan yang bersifat umum, metode ini digunakan untuk menganalisis kasus penganiayaan yang mengakibatkan kematian, sedangkan deduktif adalah pengambilan kesimpulan dari pernyataan yang bersifat umum ke pernyataan yang bersifat khusus. ${ }^{9}$ Dengan metode ini peneliti mencoba menganalisis data untuk mengungkapkan ketentuan-ketentuan hukum tentang penganiayaan juga tentang pembunuhan dalam hukum pidana Islam dan hukum pidana. Kemudian menggunakan analisis komparatif dengan cara membandingkan ketentuan yang ada dalam dua sistem hukum yang berbeda mengenai permasalahan yang sama, dengan tujuan menemukan dan mencermati perbedaan dan persamaan antar elemen dalam kedua sistem hukum tersebut, sehingga diperoleh kesimpulan sebagai penyelesaian dari persoalan yang terdapat dalam pokok permasalahan.

\section{Penganiayaan yang Menyebabkan Kematian dalam Perspektif Hukum Pidana Islam}

Pada dasarnya delik pembunuhan terklasifikasi menjadi dua golongan, yaitu:

1. Pembunuhan yang diharamkan; setiap pembunuhan karena ada unsur permusuhan dan penganiayaan.

2. Pembunuhan yang dibenarkan; setiap pembunuhan yang tidak dilatar belakangi oleh permusuhan, misalnya pembunuhan yang dilakukan oleh algojo dalam melaksanakan hukuman qishas. ${ }^{10}$

Adapun secara spesifik mayoritas ulama berpendapat bahwa tindak pidana pembunuhan dibagi dalam tiga kelompok, yaitu:

1. Pembunuhan disengaja betul - betul ('Amd Mahdh)

Menurut Abu Syujak, Pembunuhan disengaja betul - betul ('Amd Mahdh), yaitu sengaja memukulnya dengan sesuatu benda yang biasa dipergunakan untuk membunuh. ${ }^{11}$ Maksud dari "dengan sesuatu yang biasa dijadikan alat untuk membunuh" lebih umum sifatnya daripada mengatakan dengan "sesuatu alat yang tertentu atau semacamnya", kata "alat" lebih umum daripada kata "alat yang ditajamkan", seperti pisau dan semacamnya dan "alat yang berat", seperti batu besar dan semacamnya.

2. Pembunuhan menyerupai sengaja atau tersalah semata - mata (Khatha' Mahdh)

Yaitu kesalahan murni yang terjadi dalam kasus pembunuhan. Misalnya seorang pemburu atau pembidik yang pelurunya meleset hingga mengenai seorang laki-laki dan kemudian laki-laki tersebut mati karenanya maka tidak wajib qishas bagi pemburu atau pembidik tersebut. ${ }^{12}$

3. Pembunuhan Disengaja yang tersalah ( $q a t l$ al-khata')

Yaitu pembunuhan yang terjadi dengan tanpa adanya maksud membunuh, dan tindakan penganiayaan yang dilakukan adalah dengan barang yang tidak mematikan.

\footnotetext{
9 Shidiq Ardianta, Cerdas Berbahasa Indonesia (Surabaya: Pustaka Radja, 2018), 62-63.

${ }^{10}$ Wahbah az-Zuhaili, al-Figh, VI , 220.

${ }^{11}$ Abu Bakar bin Muhammad Al Husaini, Kifaayatul Akhyar, (Surabaya: tnp, tt), 125.

12 Ibid.
} 
Misalnya memukul seseorang dengan tongkat yang ringan kemudian orang tersebut mati, maka tidak wajib qishas atas orang yang memukul. ${ }^{13}$

Dalam syari'at Islam, pembunuhan diatur di dalam al-Qur'an surah An-Nissa (4) ayat 92 yang artinya: ${ }^{14}$

"Dan tidak layak bagi seorang mukmin membunuh seorang mukmin (yang lain), kecuali karena bersalah, barang siapa yang membunuh seorang mukmin dengan sengaja maka balasannya ialah jahanam, kekal ia didalamnya dan Allah murka kepadanya dan mengutuknya serta menyediakan azab yang besar baginya".

\section{Penganiayaan yang Menyebabkan Kematian dalam Perspektif Hukum Pidana}

Dalam KUHP ketentuan-ketentuan pidana tentang penganiayaan yang menyebabkan matinya orang diatur dalam pasal, ${ }^{15}$

1. Pasal 351 ayat (3)KUHP:

Yang berbunyi, "Jika perbuatan itu berakibat matinya orang yang bersalah dihukum penjara selama-lamanya 7 tahun".

2. Pasal 353 ayat (2) KUHP:

Yang berbunyi "Jika perbuatan itu berakibat matinya orang yang bersalah dihukum penjara selama-lamanya 9 tahun".

3. Pasal 354 ayat (2) KUHP:

Yang berbunyi "Jika perbuatan itu berakibat matinya orang yang bersalah dihukum dengan hukuman penjara selama-lamanya 10 tahun".

4. Pasal 355 ayat (2) KUHP:

Yang berbunyi "Jika perbuatan itu berakibat matinya orang yang bersalah dihukum dengan hukuman penjara selama-lamanya 15 tahun".

Dari uraian tersebut dapat diketahui macam-macam bentuk penganiayaan sebagai berikut:

1. Penganiayaan biasa yang diatur pada Pasal 351 KUHP ayat (3) diancam dengan hukuman penjara selama 7 tahun.

2. Penganiayaan berencana yang diatur pada Pasal 353 KUHP ayat (2) diancam dengan hukuman 9 tahun.

3. Penganiayaan berat yang diatur pada Pasal 354 KUHP ayat (2) diancam dengan hukuman 10 tahun penjara.

4. Penganiayaan berat dan berencana yang diatur pada Pasal 355 KUHP ayat (2) diancam dengan hukuman 15 tahun penjara.

Adapun penerapan sanksi terhadap delik penganiayaan yang termuat dalam KUHP, yaitu yang tercantum dalam Pasal 351-358 adalah sebagai berikut :

1. Penganiayaan berdasarkan Pasal 351 KUHP, apabila tidak mengakibatkan luka berat dan korban tidak mati dihukum dengan hukuman penjara selama-lamanya dua tahun delapan bulan atau denda sebanyak-banyaknya tiga ratus rupiah, apabila korban luka berat dihukum dengan hukuman penjara selama-lamanya lima tahun, sedangkan

\footnotetext{
${ }^{13}$ Fathul Qarib Al-mujib, 364

${ }^{14}$ Q.S. An-Nisa (4) : 92. Al Qur'an Terjemah As Syifa' (Semarang : 2001) 198

${ }^{15}$ Kitab Undang-Undang Hukum Pidana \& Kitab Undang-Undang Hukum Acara Pidana, Pasal 351-355
} 
apabila menyebabkan korban mati dihukum dengan hukuman penjara selama-lamanya tujuh tahun.

2. Penganiayaan ringan yang tidak menyebabkan sakit atau halangan untuk menjalankan jabatan atau pekerjaan, dihukum dengan hukuman penjara selama-lamanya tiga bulan atau denda sebanyak-banyaknya tiga ratu rupiah.

3. Penganiayaan berencana yang tidak mengakibatkan luka berat atau mati dihukum dengan hukuman penjara selama-lamanya empat tahun, apabila mengakibatkan luka berat dihukum dengan hukuman penjara selama-lamanya tujuh tahun, dan apabila mengakibatkan kematian dihukum dengan hukuman penjara selama-lamanya sembilan tahun.

4. Penganiayaan berat yang mengakibatkan luka berat dihukum dengan hukuman penjara selama-lamanya delapan tahun dan apabila mengakibatkan kematian dihukum dengan hukuman penjara selama-lamanya sepuluh tahun.

5. Penganiayaan berat dan berencana yang mengakibatkan luka berat dihukum dengan hukuman penjara selama-lamanya dua belas tahun dan apabila mengakibatkan kematian dihukum dengan hukuman penjara selama-lamanya lima belas tahun.

6. Turut dalam perkelahian, apabila mengakibatkan luka berat dihukum dengan hukuman penjara selama-lamanya dua tahun delapan bulan dan apabila mengakibatkan kematian dihukum dengan hukuman penjara selama-lamanya empat tahun.

Khusus bagi tindak pidana penganiayaan yang mengakibatkan orangnya mati, tidak dapat dihindarkan untuk tidak mendakwakan Pasal 338 KUHP bahkan Pasal 340 KUHP karena permasalahan adalah pada unsur "dolus" atau "bentuk kesengajaan" terutama dengan bentuk "dolus eventualis".

Dalam KUHP, pidana penjara merupakan salah satu pidana pokok yang berwujud perampasan atau pengurangan kemerdekaan seseorang, dalam aarti bahwa seseorang tidak dapat bertindak dengan bebas selama dalam penjara, ia harus mematuhi segala peraturan yang ada dalam penjara tersebut. Lamanya berada dalam penjara tergantung pada jenis hukuman dari perbuatan melanggar hukum yang dilakukannya.

Selain hukuman penjara, KUHP juga terkadang menyertakan pidana pokok lain yaitu pidana denda, seperti dalam KUHP Pasal 352 tentang penganiayaan ringan. Dalam pasal tersebut disebutkan bahwa penganiayaan ringan yang tidak menyebabkan sakit atau halangan untuk menjalankan jabatan atau pekerjaan, dihukum dengan hukuman penjara selama-lamanya tiga bulan atau denda sebanyak-banyaknya tiga ratus rupiah. Pidana berupa denda tersebut tidak ditentukan ukuran maksimumnya secara umum, sebagaimana tercantum dalam Pasal 30 ayat (1) KUHP sebesar dua puluh lima sen (dikalikan 15 menurut Undang-undang No. 18/Prp/1960). ${ }^{16}$

Apabila berdasarkan Pasal 90 KUHP dalam mengartikan luka berat dan diterapkan dalam pasal-pasal penganiayaan, yakni dalam Pasal 351 ayat (2) KUHP tentang penganiayaan biasa yang mengakibatkan luka berat yang menyatakan: “Jika perbuatan itu berakibat luka berat, yang bersalah dihukum dengan hukuman penjara selama-lamanya lima tahun", maka perbuatan penganiayaan dalam kasus yang dibicarakan merupakan penganiayaan yang mengakibatkan luka berat dengan ancaman hukuman penjara selama-lamanya lima tahun.

\footnotetext{
${ }^{16}$ Rudy T. Erwin dan J.T. Prasetyo, Himpunan Undang-undang., 342-346.
} 
Pasal yang lain dari penganiayaan yang mengakibatkan luka berat adalah Pasal 353 KUHP tentang penganiayaan yang direncanakan terlebih dahulu, bunyi dari pasal tersebut :

1. Penganiayaan dengan sudah direncanakan lebih dahulu dihukum dengan hukuman penjara selama-lamanya empat tahun.

2. Jika perbuatan itu berakibat luka berat, yang bersalah dihukum dengan hukuman penjara selama-lamanya tujuh tahun.

3. Jika perbuatan itu berakibat orangnya mati, yang bersalah dihukum dengan hukuman penjara selama-lamanya sembilan tahun.

Dalam Pasal 353 ayat (2) tersebut disebutkan apabila penganiayaan berencana itu mengakibatkan luka berat maka pelakunya diancam dengan hukuman penjara selamalamanya tujuh tahun. Kemudian jika dimasukkan ke dalam kasus yang dibahas, apabila dalam kasus tersebut terbukti ada unsur perencanaan terlebih dahulu maka kasus yang dikemukakan bisa dikategorikan sebagai penganiayaan berencana yang mengakibatkan luka berat dengan ancaman hukuman penjara selama-lamanya tujuh tahun.

Pasal 354 KUHP juga menjelaskan penganiayaan yang juga berakibat luka berat dan jenis dari penganiayaan tersebut juga merupakan penganiayaan berat, bunyi Pasal 354 KUHP

1. Barangsiapa dengan sengaja melukai berat orang lain dihukum dengan hukuman penjara selama-lamanya delapan tahun.

2. Jika perbuatan itu berakibat orangnya mati, yang bersalah dihukum dengan hukuman penjara selama-lamanya sepuluh tahun.

Pembagian dari jenis ini dikategorikan berdasar akibat yang ditimbulkannya yaitu luka berat dan kematian, jadi apabila kasus yang dikemukakan dikategorikan ke dalam jenis ini maka ancaman hukumannya adalah selama-lamanya delapan tahun.

Yang terakhir adalah Pasal 355 KUHP yaitu tentang penganiayaan berat dan berencana. Pasal ini merupakan gabungan dari dua pasal sebelumnya. Dalam pasal ini disebutkan :

1. Penganiayaan berat dengan direncanakan terlebih dahulu, dihukum dengan hukuman penjara selama-lamanya dua belas tahun.

2. Jika perbuatan itu berakibat orangnya mati, yang bersalah dihukum dengan hukuman penjara selama-lamanya lima belas tahun.

Dalam Pasal di atas khususnya pada ayat (1) dijelaskan bahwa penganiayan berat yang direncanakan lebih dahulu diancam dengan hukuman penjara selama-lamanya dua belas tahun, penggolongan penganiayaan tersebut juga berdasarkan dari akibat yang ditimbulkan yaitu luka berat serta kematian, jadi kasus yang dikemukakan juga bisa dimasukkan ke dalam jenis penganiayaan ini apabila memang ada unsur direncanakan terlebih dahulu.

\section{Perbandingan Delik Penganiayaan yang Mengakibatkan Kematian antara Hukum Pidana Islam dan Hukum Pidana}

Berdasar pada pembahasan sebelumnya, penyusun dapat menyimpulkan bahwa antara hukum pidana Islam dan hukum pidana sama-sama melarang adanya perbuatan penganiayaan serta pembunuhan, dan telah mengatur keduanya dengan memberikan ancaman hukuman tertentu. Kedua sistem hukum tersebut juga pada dasarnya sama dalam merumuskan delik penganiayaan serta delik pembunuhan, yaitu penganiayaan merupakan suatu perbuatan yang mengakibatkan rasa sakit terhadap orang lain secara melawan hukum 
sedangkan pembunuhan dirumuskan sebagai tindakan yang mengakibatkan hilangnya nyawa atau jiwa orang lain tanpa adanya hak yang sah.

Dalam mengartikan sebuah delik atau tindakan yang dapat dipidana haruslah ada unsur-unsur tertentu di dalamnya, unsur-unsur tersebut menurut hukum positif adalah suatu perbuatan, perbuatan itu dilarang dan diancam dengan hukuman, dan perbuatan itu dilakukan oleh orang yang dapat dipertanggung jawabkan. ${ }^{17}$

Unsur-unsur yang ada dalam hukum pidana tersebut sama dengan unsur-unsur yang ada dalam hukum pidana Islam, unsur-unsur tersebut adalah sebagai berikut:

1. Unsur formil, yaitu adanya ketentuan atau aturan yang menunjukkan larangan terhadap suatu perbuatan yang diancam hukuman.

2. Unsur materiil, yaitu adanya perbuatan yang melawan hukum baik itu perbuatan nyatanyata berbuat atau sikap tidak berbuat.

3. Unsur moril, yaitu unsur yang terdapat pada pelaku. Pelaku jarimah haruslah mukallaf, yaitu orang yang dapat dimintai pertanggungjawaban terhadap jarimah yang dilakukannya. ${ }^{18}$

Ditinjau dari hukum pidana Islam, secara umum ketentuan hukuman bagi pelaku penganiayaan yang tertuang dalam al-Qur'an maupun beberapa hadis dapat disimpulkan bahwa terdapat beberapa jenis hukuman untuk delik penganiayaan, yang besar kecilnya tergantung dari tingkat penganiayaan itu sendiri. Hukuman tersebut adalah berupa qisas, diyat, ta'zir serta kifarah. Penetapan dari sanksi tersebut disesuaikan pada bentuk dari kejahatan yang dilakukan.

Sedangkan untuk delik pembunuhan sanksi hukumannya lebih berat lagi, yaitu hukum qisas dengan cara membalas membunuh pelaku delik pembunuhan, hukum qisas ini dilakukan oleh wali si korban (waliy ad-dam). Akan tetapi selain sanksi qisas tersebut bagi waliy ad-dam diperbolehkan memilih jenis sanksi hukuman bagi pelaku, yaitu antara hukum qisas atau mengambil diyat atau bahkan memaafkan pelaku. Hal ini berlaku pada jenis pembunuhan yang dilakukan secara sengaja.

Pelaksanaan diyat dengan cara menyerahkan sejumlah harta kepada wali si korban haruslah sesuai dengan ketentuan yang telah ditetapkan oleh syara'. Harta tersebut bisa berasal dari harta si pelaku sendiri atau juga dari 'aqilah. ${ }^{19}$ Untuk pembunuhan sengaja diyat diambil dari harta kekayaan si pelaku, sedangkan untuk pembunuhan serupa dengan sengaja atau pembunuhan karena kesalahan ditanggung oleh 'aqilah, hal ini berdasarkan hadis.

Dalam hukum pidana Islam, qisas juga bisa berupa balasan terhadap tindak penganiayaan, yaitu dengan cara membalas serupa apa yang dilakukan oleh pelaku baik itu yang menyebabkan cacat, seperti terpotong tangan atau hanya menimbulkan rasa sakit seperti dalam hal pemukulan.

\footnotetext{
${ }_{17}$ Dahlan, Problematika Keadilan Dalam Penerapan Pidana Terhadap Penyalah Guna Narkotika, (Yogyakarta : Budi Utama, 2017), 16.

18 Ahmad Wardi Muslich, Pengantar dan Azas Hukum Pidana Islam (Fikih Jinayah), (Jakarta : Sinar Grafika, 2014 ), 11.

19 Menurut Dr. Muhammad Muhsin Khan, aqilah berarti asabah yang menunjukkan hubungan ayang dengan pembunuh. Dalam pembayaran diyat harta yang berasal dari aqilah juga dapat dimaksud sebagai perwakilan saudara terdekat pelaku pembunuhan untuk membayarkan diyat kepada keluarga terbunuh.

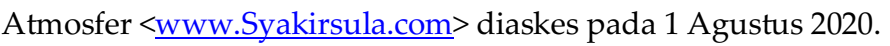


Kemudian mengenai hukuman yang berupa pidana penjara, dalam hukum pidana Islam secara jelas tidak disebutkan, namun sebagaimana pendapat sebagian besar ulama hukuman penjara adalah sebagai wujud dari hukuman pengasingan. Hukuman pengasingan tersebut ada di dalam ketentuan mengenai jarimah perampokan yang pelakunya hanya menakut-nakuti masyarakat tanpa melakukan perampasan harta maupun pembunuhan. Akan tetapi ketentuan lamanya pengasingan tersebut tidak ditentukan, yaitu sampai si pelaku bertaubat.

Dalam hukum pidana, ketentuan sanksi hukuman bagi pelaku penganiayaan disertakan dalam pasal yang mengatur ketentuan mengenai penganiayaan itu sendiri, yaitu pada Pasal 351-358 KUHP. Dalam pasal-pasal tersebut termuat ancaman hukuman bagi pelaku penganiayaan sesuai dengan jenis penganiayaannya, sanksi hukuman tersebut berupa hukuman penjara serta hukuman denda. Dalam hal delik penganiayaan ini tidak ditetapkan adanya hukuman mati, karena hukuman mati dalam hal kejahatan hanya ada dalam delik pembunuhan, itu pun tidak semua pembunuhan diancam dengan hukuman mati. Dalam KUHP ancaman hukuman mati untuk delik pembunuhan hanya pada jenis pembunuhan berencana yang tertuang dalam Pasal 340 KUHP dengan ancaman hukuman mati atau penjara seumur hidup atau penjara selama-lamanya dua puluh tahun. Sedangkan dalam delik penganiayaan sendiri hukuman penjara paling lama adalah lima belas tahun, yaitu pada jenis penganiayaan berat dan berencana yang mengakibatkan kematian si korban, hal ini tertuang dalam Pasal 354 KUHP selain mengatur penganiayaan berat dan berencana yang mengakibatkan luka berat dengan ancaman hukuman penjara selama-lamanya dua belas tahun.

Berdasarkan pada ketentuan hukuman dari kedua sistem hukum tersebut terdapat perbedaan jenis hukuman untuk delik penganiayaan maupun pembunuhan, yaitu adanya hukuman penjara dalam hukum pidana, sedangkan dalam hukum pidana Islam tidak mengenal adanya hukuman penjara.

Dalam hukum pidana Islam, hukuman mati merupakan jenis hukuman yang dikenakan terhadap orang yang melakukan pembunuhan dengan sengaja, yang disebut dengan qisas (pembalasan). Di dalam qisas terdapat hak manusia yang berkaitan dengan kepentingan pribadi seseorang. Sehingga penetapan terhadap suatu hukuman dapat digugurkan apabila pihak wali korban memaafkan pelaku kejahatan tersebut.

Dalam hukum positif (KUHP), hukuman mati merupakan jenis pidana yang paling berat dari susunan hukuman yang diatur dalam Pasal 10 KUHP dan merupakan hukuman pokok yang bersifat khusus dengan pertimbangan yang khusus pula. Mengenai keberadaan pidana mati sampai sekarang masih dipertahankan meskipun banyak muncul pro dan kontra di kalangan pakar-pakar hukum.

Sebagian pakar hukum menyetujui diberlakukannya hukuman mati dengan alasan bahwa hukuman mati itu diperlukan dan ditujukan kepada kejahatan-kejahatan tertentu yang digolongkan pada kejahatan berat dan bagi penjahat yang sudah tidak dapat diperbaiki lagi. Sebagian pakar hukum lain menolak pelaksanaan hukuman mati tersebut dengan alasan pemberlakuan hukuman tersebut bertentangan dengan hak asasi manusia dan dianggap tidak berperikemanusiaan dan apabila terdapat kekeliruan Hakim dalam menjatuhkan vonis, maka vonis tersebut tidak dapat diperbaharui lagi. 


\section{Kesimpulan}

Kesimpulan yang dapat diambil dari penelitian ini dapat dibagi menjadi tiga aspek. Yang pertama dalam hukum Islam ada beberapa macam jenis hukuman yaitu, qisas, diyat, ta'zir, penghalangan pelaku dari mendapat wasiat dan warisan, serta adanya kifarah. Penganiayaan yang menyebabkan kematian dalam hukum pidana islam dapat dikategorikan sebagai pembunuhan disengaja yang tersalah ( qatl al-khata'). Sementara yang kedua, di dalam hukum pidana positif sanksi terhadap pelaku penganiayaan ada dua macam, yaitu pidana penjara dan pidana denda. Selain itu juga dapat disertai pidana tambahan. Tindak pidana penganiayaan dijelaskan dalam Pasal 351-358 KUHP. Maka dari itu Antara hukum pidana Islam dan hukum pidana positif sama-sama melarang adanya perbuatan penganiayaan yang menyebabkan kematian serta pembunuhan dan telah mengatur keduanya dengan memberikan ancaman hukuman tertentu. Kedua sistem tersebut juga pada dasarnya sama dalam merumuskan delik penganiayaan yang menyebabkan kematian. Berdasarkan pada ketentuan hukuman dari kedua sistem hukum tersebut terdapat perbedaan jenis hukuman untuk delik penganiayaan maupun pembunuhan, yaitu adanya hukuman penjara dalam hukum pidana positif, sedangkan dalam hukum pidana Islam tidak mengenal adanya hukuman penjara.

\section{Daftar Pustaka}

\section{Buku}

Al Husaini, Abu Bakar bin Muhammad. Kifaayatul Akhyar. Surabaya.

Ardianta, Shidiq. 2018. Cerdas Berbahasa Indonesia. Surabaya: Pustaka Radja.

Az-Zuhaili, Wahbah. t.t. al-Figh, VI: t.n.p.

Buchari, said. Hukum Pidana Materil, Bandung: FH UNPAS.

Dahlan. 2017. Problematika Keadilan Dalam Penerapan Hukum Pidana Terhadap Penyalah Guna Narkotika. Yogyakarta: Budi Utama.

Erwin, Rudy T. \& J.T. Prasetyo. t.t. Himpunan Undang-undang: t.n.p.

Fathul Qarib Al-Mujib.

Fikih Natsir, Muhammad. 2019. Korporasi Antara Sanksi Dan Tindak Pidana Lingkungan Di Aceh. Yogyakarta: Budi Utama.

IAIN Jember.2018. Pedoman Penulisan Karya Ilmiah. Jember: IAIN Jember Press.

Muhajir, Noeng. 1998. Metodologi Penelitian Kualitatif, Cet. Ke-4. Yogyakarta: Roke Sarasin.

Muslich, Ahmad Wardi. 2004. Pengantar dan Azas Hukum Pidana Islam. Jakarta: Sinar Grafika.

Rokhmadi. 2015. Hukum Pidana Islam. Semarang: Karya Abadi Jaya.

Soekanto, Soerjono. 1986. Pengantar Penelitian Hukum, Cet. Ke-3. Jakarta: UI-P ress.

Surakhmad, Winarno. 1994. Pengantar Penelitian Ilmiah: Dasar, Metode, Tehnik, Cet. Ke-7. Bandung: t.n.p.

T.n. 2001. Al Qur'an Terjemah As Syifa'. Semarang: t.n.p.

\section{Perundang-undangan}

Kitab Undang-Undang Hukum Pidana \& Kitab Undang-Undang Hukum Acara Pidana. Undang-Undang No. 18/Prp/1960. 


\section{Laman}

Atmosfer, www.Syakirsula.com, diaskes pada 1 Agustus 2020.

Guru Geografi, www.gurugeografi.id, diakses pada 1 September 2018. 